\title{
A New Cave-Dwelling Eyeless Spider of the Genus Coelotes (Araneae: Amaurobiidae) from Okinawa Island, the Ryukyu Islands, Japan, with Notes on Possible Parthenogenesis
}

\author{
Matsuei Shimojana $^{1} \&$ Moritaka Nishihira $^{2}$ \\ ${ }^{1}$ College of Education, University of the Ryukyus, Nishihara, Okinawa, 903-.0129 Japan \\ ${ }^{2}$ Biological Institute, Graduate School of Science, Tohoku University, Sendai, 980-8578 Japan. \\ E-mail: moritaka@mail.cc.tohoku.ac.jp
}

\begin{abstract}
A small troglobiontic coelotine spider is described under the name of Coelotes troglocaecus sp. n. found in limestone caves on Okinawa Island, Japan. This is the first record of an eyeless coelotine spider. Morphological description is given in comparison with a sympatric Coelotes okinawensis. Extensive field survey over the Ryukyu Islands showed that the new species is endemic to Okinawa Island, where it has been found rather widely but exclusively in limestone caves. The population density was extremely low, and the facts that only females have been collected and that they have extremely degenerated structures in epigynum projections and degenerated copulatory opening for coupling strongly suggest parthenogenetic reproduction. It has some additional morphological traits which seem adaptive to the life in the caves. Specialization to cave habitat is discussed in relation to the geological history of the Ryukyu Islands.
\end{abstract}

Key words - Coelotes, Okinawa Island, cave, parthenogenesis, eyeless spider

There has been no record of eyeless coelotine spiders from Japan. Shimojana (1977, 1979, etc) has conducted arachnological surveys in the Ryukyu Islands and investigated the spider fauna at 1,013 localities including 260 limestone caves (Table 1). Our extensive survey yielded four adult and three subadult specimens of eyeless spiders belonging to the genus Coelotes. Since 1971, we have been trying intermittently to find males of this undescribed species, but this was not successful.

This undescribed species is characterized by morphological traits such as eyelessness, a degenerated copulatory opening, degenerated reproductive organ (spermathecae, spermathecal duct), body coloration and thin skin, etc. This troglobiontic coelotine spider is very rare with very low population density in Okinawa Island. The degenerated morphological characters of reproductive organs, restricted habitat and a low population density strongly suggest a possibility of parthenogenesis.

In this paper, we describe this eyeless coelotine spider under the name of Coelotes troglocaecus sp. n. Additionally, we compare it with the sympatric Coelotes okinawensis Shimojana 1989. Furthermore, we discuss its geographical distribution in relation to the geological history of Okinawa Island.

\section{Materials and Methods}

Materials studied for description were collected in limestone caves on Okinawa Island. Morphological characters were examined using a Leica MZ12 binocular microscope equipped with a drawing device. All measurements are in $\mathrm{mm}$ and taken using a micrometer attached to the binocular microscope. Measurements of chelicerae, 
palpi and legs were taken in both lateral sides. For describing spiniformation, a new spiniformation formula was proposed for legs (see description). Coloration of holotype was recorded when the specimen was alive, but that of the paratypes are based on the specimens kept in $70 \%$ ethanol solution. Three subadult specimens were not used for the present study.

Paratypes do not have abdomens, because they were used for the examination of internal genitalia. Because the most striking and remarkable morphological character of the species is the absence of eyes, we included these specimens in this study.

Coelotes troglocaecus sp. nov.

[Japanese name: Okinawa-horaanayachigumo]

(Figs. 1-12, 16-27)

Type and type locality: The female (holotype) was collected in Nobaru-gama cave at Motobu Peninsula on Okinawa Island in the Ryukyu Islands (Fig. 1) on 22 July 1978 by M. Shimojana. Additional two adult specimens available were also all females (paratypes). One of them was collected on 9 September 1972 from the same cave, and another one was collected on 8 July 1972 from the Maya-gama cave (Fig. 1). The holotype is deposited in the collection of Department of Zoology, National Science Museum (Nat. Hist.), Tokyo.

Habitat: Only known from limestone caves. We have conducted a field survey at about 1,013 localities outside of caves (Table 1), yet not a single specimen has been found. This fact strongly suggests that the species is troglobiontic.

Etymology: This spider is a true cave dweller, and was named after its restricted habitat.

Diagnosis: This species is characterized and distinguished from other congeners by lacking eyes (Figs. 2,3), diminutive projections on the epigynum and simple structure of genitalia (Figs. 10-12), pale coloration of spines, thin cuticle, lacking ring flecks (Fig. 2), decreased number of teeth of lower claws of tarsi of all legs (Fig. 17), and abdominal dorsal surface lacking chevron marks (Fig. 2) (see description).

Description: Female (Holotype): Total length $5.46 \mathrm{~mm}$; cephalothorax $2.40 \mathrm{~mm}$ long and $1.60 \mathrm{~mm}$ wide; abdomen $3.00 \mathrm{~mm}$ long and $1.60 \mathrm{~mm}$ wide, ellipse-shaped without chevron marks, and dorsal surface covered evenly by pale short hairs. The ratio of cephalic region 10: 16. The ratio of height of head to that of thorax 14: 10. The eyes entirely absent (Figs. 2, 3). Clypeus with one long and four short bristles (Fig. 5). Median furrow distinct, $0.32 \mathrm{~mm}$ long (Fig. 3). Cervical grooves and three pairs of radial furrows distinct (Figs. 2, 3). Both frontal corners of head weakly chitinized (Fig. $3)$.

Chelicerae geniculated, $0.96 \mathrm{~mm}$ long and $0.70 \mathrm{~mm}$ wide, with a lateral condyle (Fig. 5). Promargin of fang furrows with three teeth and retromargin with two teeth (Fig. 6). Number and arrangements of the left marginal teeth (promargin/retromargin) same as on the right side. Fang $0.9 \mathrm{~mm}$ long and hook-shaped (Figs. 5, 6).

Maxilla longer than wide 17: 10 in ratio, dorsal side with many long bristles (Fig. 7). Inner edge of maxilla slightly curved with a serration. Labium wedge-shaped, extending beyond the middle of maxillae, slightly wider than long 20: 19 in ratio, with some long and short hairs, the notch of the labium distinct (Fig. 7). Sternum shieldshaped, slightly inflated, longer than wide 13: 10 in ratio (Fig. 8). Anterior margin of sternum gently undulated, covered with many short hairs interspersed with bristles and their lengths increasing towards marginal direction (Fig. 8). Posterior process of 


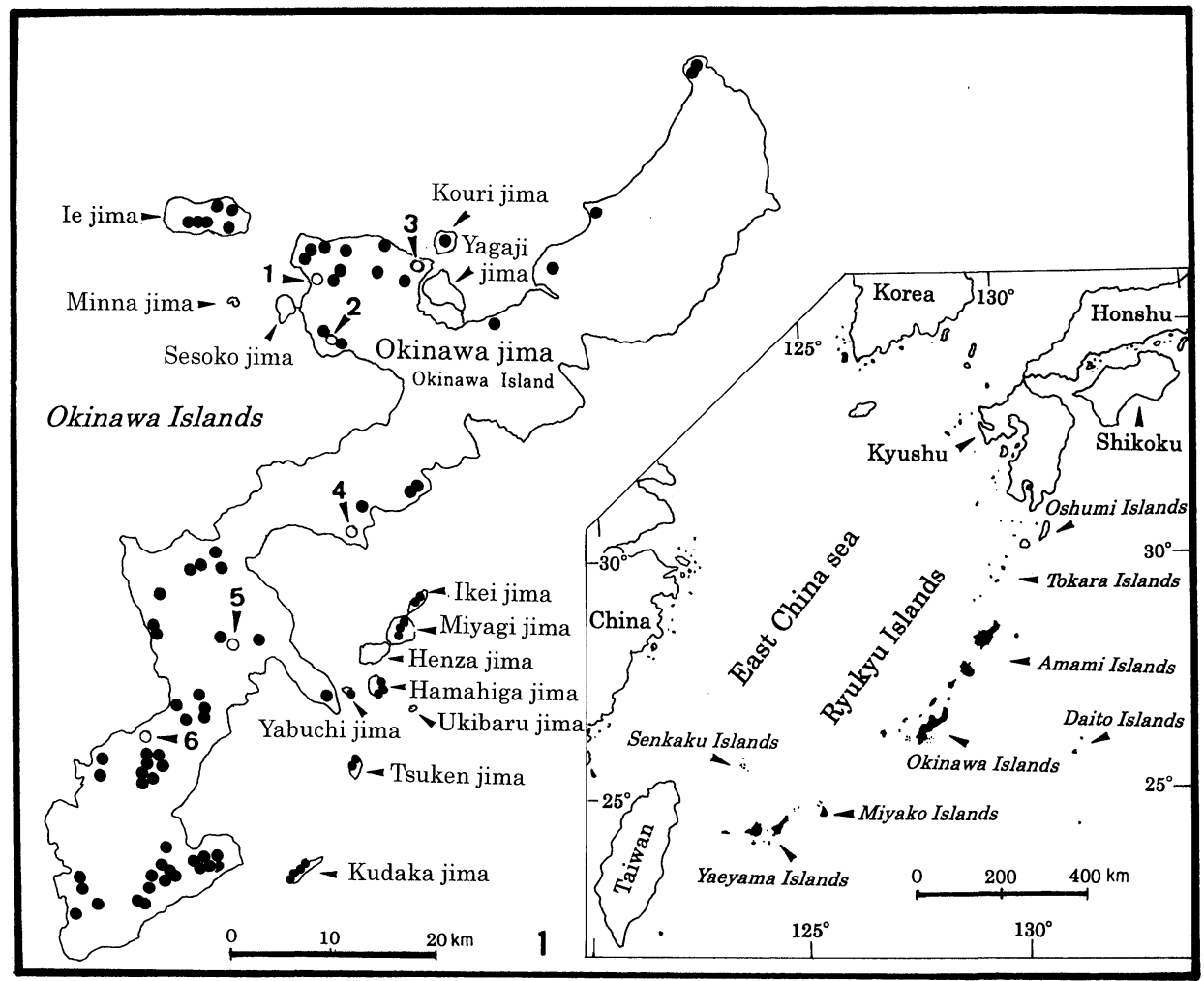

Fig. 1. Location of the Ryukyu Islands (insertion) and the distribution of the caves where spider faunal surveys were conducted. Since Coelotes troglocaecus sp. n. has been found in several limestone caves only on Okinawa Island, localities of caves surveyed on other island groups are not shown. For the total number of localities visited for spider surveys, see Table 1. Solid circles indicate locations of caves surveyed where Coelotes troglocaecus sp. n. was not found; open circles indicate localities of caves where Coelotes troglocaecus sp. n. was found. 1, Nobaru-gama cave, Motobu Village (Motobu limestone); 2, Nishibumabaru cave, Nago City (Motobu limestone); 3, Tametomo-no-hora'ana cave, Nakijin Village (Ryukyu limestone); 4, Nisshu-do cave, Kin Village (Ryukyu limestone); 5, Yaejima-no-iwaya cave, Okinawa City (Ryukyu limestone); 6, Maya-gama cave, Ginowan City (Ryukyu limestone)

sternum pointed with some long hairs (Fig. 9), $1.06 \mathrm{~mm}$ long, separating coxae of legs IV.

Diminutive epigynal projections of this new species situated anteriorly of epigynum, widely separated from each other (Figs. 10, 12). Copulatory opening and duct indistinct. Internal genitalia visible through very thin cuticle from ventral side of abdomen (Fig. 11). Spermathecae small, widely separated, spermathecal bases not apparent.

Measurements of segments of legs, palpi and numbers of teeth of tarsal claws are shown in Table 2. Legs IV longest (Fig. 2), ratio of length of leg IV to that of leg III 13: 10. Leg formula 4, 1, 2, 3. The lengths of left and right legs not strictly identical, but slightly different for all legs (Table 2). Number of teeth on upper tarsal claws (Fig. 17) slightly dissimilar for any pair of legs and increasing from legs I to IV. The number of 

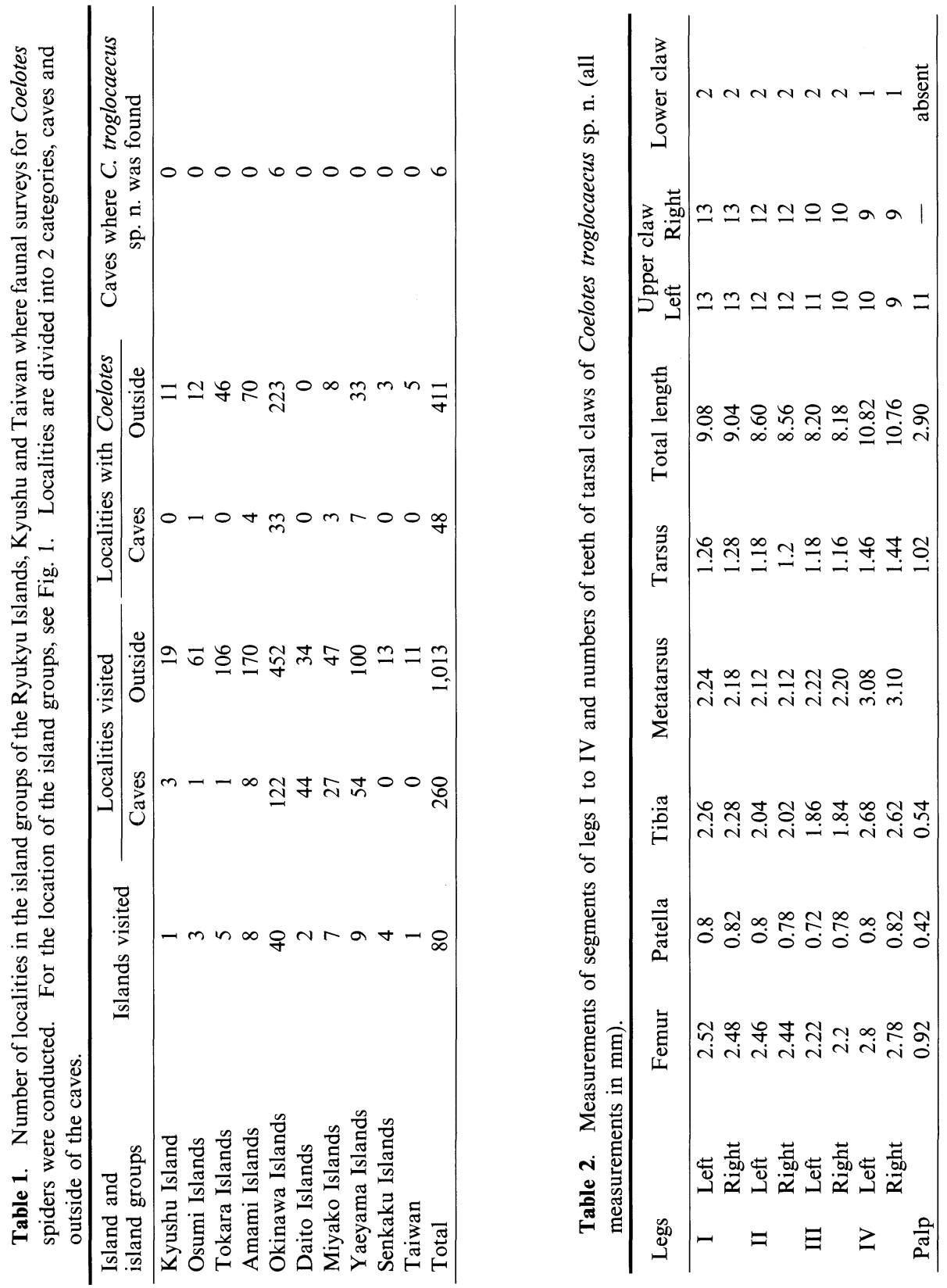


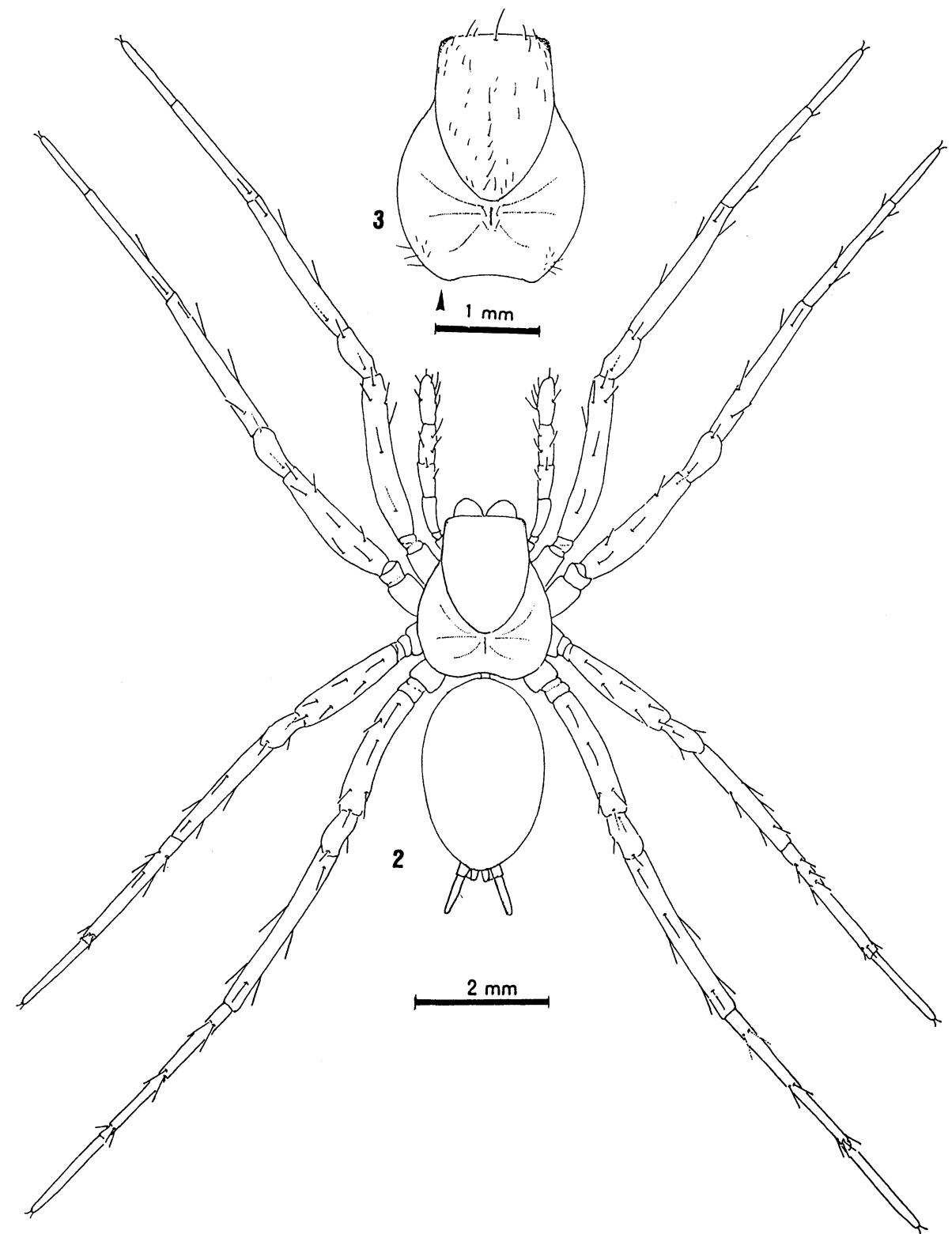

Figs. 2-3. Coelotes troglocaecus sp. n. (holotype, female). - 2, Dorsal view (hairs and bristles omitted, dashed line indicates broken spines); 3 , surface of the carapace (dorsal view)

teeth on each lower claw the same for all legs except for leg IV (Table 2). The trichobothria are located always on mid-dorsal surface, the number of trichobothria is six lying on metatarsi of legs I to III, and seven on those of leg IV, five on tarsi of legs I to III and six on those of leg IV. The lengths of trichobothria on metatarsi and tarsi 

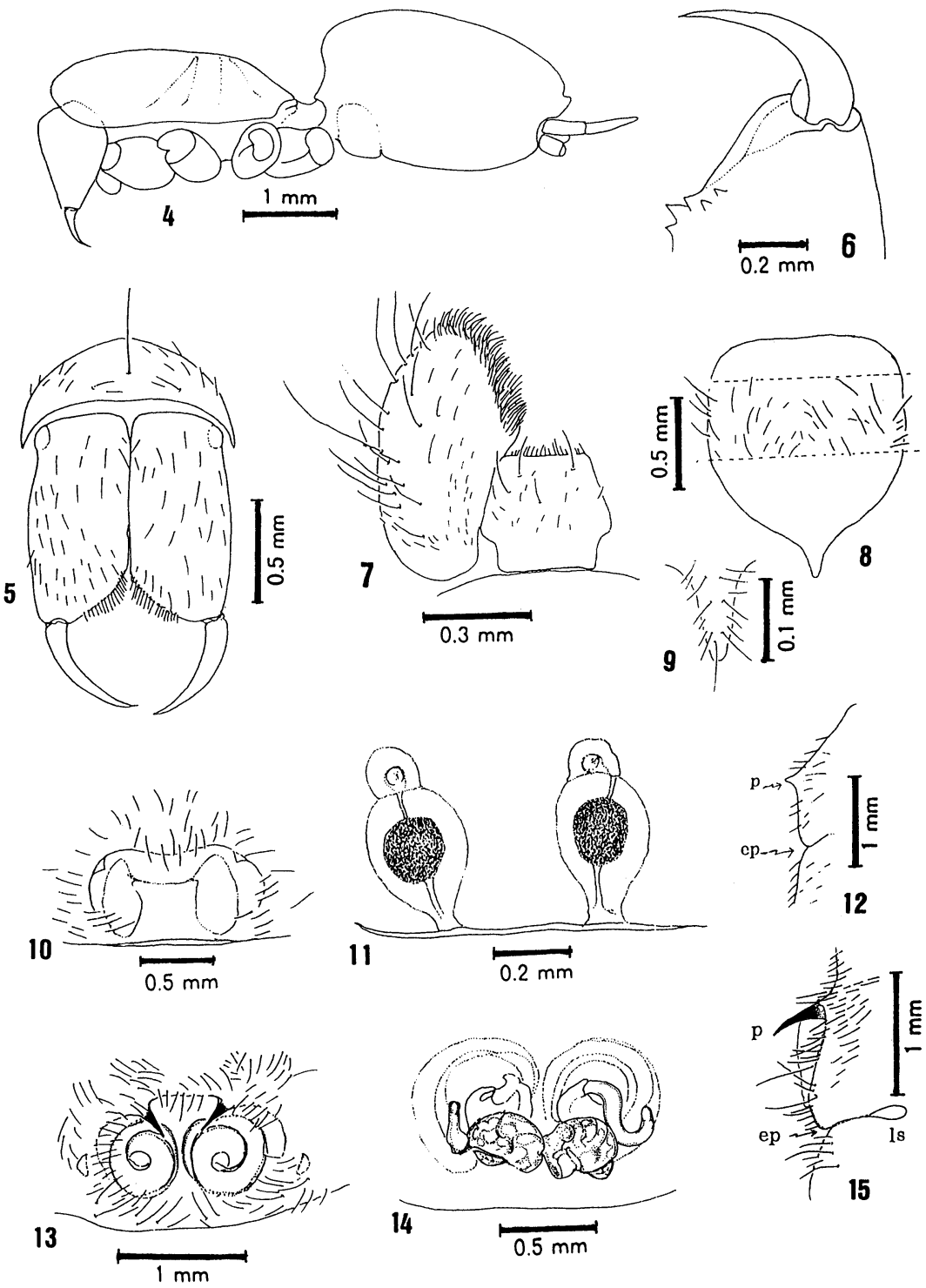

Figs. 4-12. Coelotes troglocaecus sp. n. (holotype, female); 4, lateral view of body (hairs and bristles are omitted); 5, frontal view of head and chelicerae; 6, marginal teeth and fang of left chelicera (inner view); 7 , ventral view of maxillae and labium; 8, ventral view of sternum; 9 , process of sternum (ventral view); 10, ventral view of epigynum; 11 , dorsal view of genitalia; 12, lateral view of epigynum, $\mathrm{p}$ indicates the projection, ep indicates the epigastric furrow; 13-15: Coelotes okinawensis (female) from Nobarugama cave, Okinawa Island; 13, ventral view of epigynum; 14, dorsal view of genitalia; 15 , lateral view of epigynum; $p$ indicates projection, ep epigastric furrow, ls lung slit. 

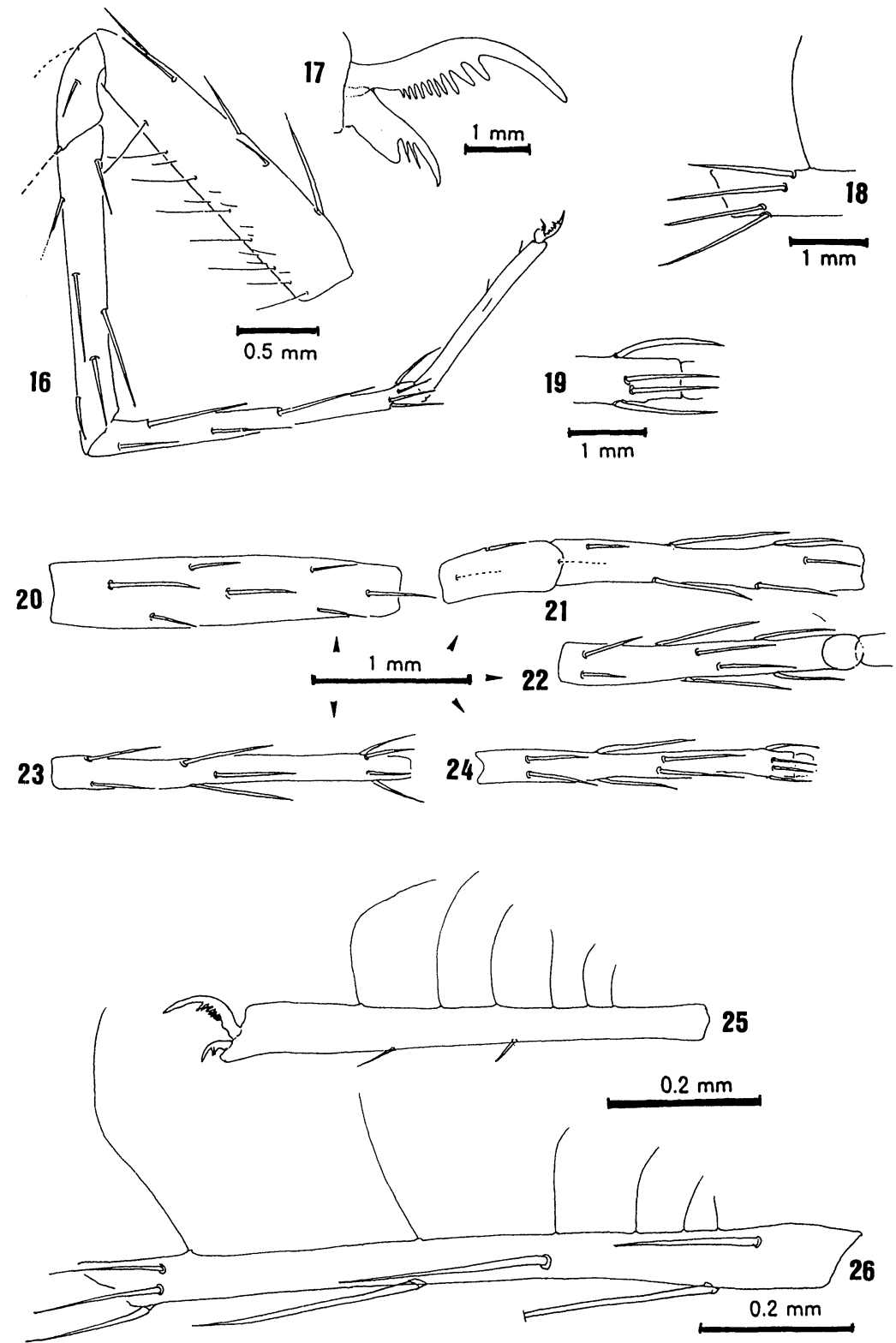

Figs. 16-24. Coelotes troglocaecus sp. n. (holotype, female, left leg III); 16, retrolateral view (trichobothria omitted); 17, teeth on tarsal claws (lateral view); 18, lateral view of distal spines of metatarsus with distal trichobothrium; 19, ventral view of distal spines of metatarsus; 20 , dorsal view of femur; 21 , dorsal view of patella and tibia; 22 , ventral view of tibia; 23, dorsal view of metatarsus (trichobothria omitted); 24, ventral view of metatarsus. 25-26: Trichobothria on tarsus and metatarsus of Coelotes troglocaecus sp. n. (holotype, female, right leg III); 25, retrolateral view of tarsus (bristles and hairs omitted); 26 , retrolateral view of metatarsus (bristles and hairs omitted). 
definitely increasing distally, distal ones always being longest and proximal ones shortest (Figs. 25, 26). The length of trichobothria on metatarsi and tarsi ranging from 0.08 to $0.94 \mathrm{~mm}$. The positions of trichobothria on tarsi of each leg are similarly on left and right legs but trichobothrial lengths on metatarsi and tarsi are slightly different on both sides.

Arrangements of spines on leg segments and spiniformation are presented in Fig. 27. The spiniformation formula introduced in this study consists of numbers 0 to 3 , and small letters $1, r$ and $d$, which are shown either in parentheses or not. I to IV show leg I to leg IV. In the description, numbers indicate numbers of spines, $r$ in parentheses means right and 1 means left, and if there is neither $r$ nor 1 , it means right and left have equal spiniformation. Spiniformations on each segment of Coelotes troglocaecus sp. $\mathrm{n}$. are as follows; Femora: dorsal I and IV(r)1-0-1-2-1, II(1) and III 1-2-1-2-1, II(r)1-11-1-1, IV(1)1-1-1-2-1, (r)1-0-1-2-1; retrolateral I 0-0-1; Patellae: dorsal I to IV lp-la, III $0-1 \mathrm{a}(\mathrm{r})$, retrolateral III to IV $\mathrm{lm}$; Tibiae: dorsal I to II $1-0-1$, III $1-1-1$, prolateral III(1) - IV(1) 0-0-1, retrolateral I. III 0-1(1). IV 0-1-1, II and III (r) 0-0-1, ventral I to III(1) 2-2-0, III(r) and IV 2-2-1; Metatarsi: dorsal III(1) and IV 2-2-2, III(r) 2-0-2. prolateral III(1) 0-1-1d. lv, III(r) 1-1-1d, IV(r) 1-0-1d, retrolateral I(1) to III(l) 0-0-1d., $1 \mathrm{v}$, II.III(r). IV(r) 0-1-1, IV(1) 0-0-1d, ventral I. II. III 2-2-1d, IV 2-2-2-3d(1), 2-21(r). Tarsi: prolateral I(1), III and IV(1) 0-1-0, retrolateral III and IV. 0-1-0; Ventral III and IV $0-1-1$.

The positions and the numbers of spines on each segment of leg I are similar on left and right legs except for tarsi, while leg IV bears 40 to 41 spines with their positions on each segment differring on left and right legs. The latero-ventral spines on metatarsi of legs II and III appear only on distal end of both segments (Fig. 18).

Morphological characters of Coelotes troglocaecus sp. n. and sympatric C. okinawensis are compared (Table 3). Table 3 and Figs. 10-15 give comparison of the

Table 3. Comparison of female morphological characters of Coelotes troglocaecus sp. n. and sympatric C. okinawensis.

\begin{tabular}{|c|c|c|}
\hline & C. troglocaecus & C. okinawensis \\
\hline Total length $(\mathrm{mm})$ & 5.46 & 7.91 \\
\hline Body color & Pale brown & Grayish brown to blackish brown \\
\hline Flecks on carapace & Absent & Present \\
\hline Eyes & 0 & 8 \\
\hline \multicolumn{3}{|l|}{ Cheliceral teeth } \\
\hline Promargin & 3 & 5 \\
\hline Retromargin & 2 & 4 \\
\hline Ring flecks on legs & Absent & Present \\
\hline \multicolumn{3}{|l|}{ Tarsal claws (mm) } \\
\hline Upper claw & 9 to 11 & 10 to 13 \\
\hline Lower claw & 2 & 4 \\
\hline \multicolumn{3}{|l|}{ Flecks on abdomen } \\
\hline Dorsal surface & Absent & Chevron flecks \\
\hline \multicolumn{3}{|l|}{ Epigynum } \\
\hline Shape & Smooth & Spirally concaved \\
\hline Copulatoy opening & Absent & Well developed \\
\hline \multirow[t]{2}{*}{ Projection } & Dimunitive, & Well developed \\
\hline & Very small & Long, strongly pointed and cuticularized \\
\hline Genitalia & Poorly developed & Well developed \\
\hline \multirow[t]{2}{*}{ Spermathecae } & Simple structure, & Long, convoluted \\
\hline & Widely separated & Close together \\
\hline
\end{tabular}




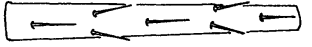

$1-2-1-2-1$

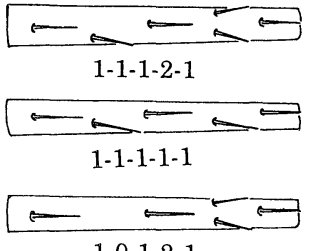

$1-0-1-2-1$

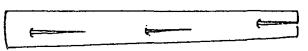

1-0-1-0-1

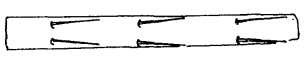

$2-2-2$

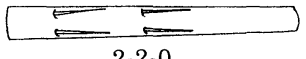

$2-2-0$

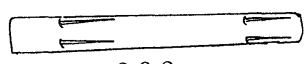

$2-0-2$

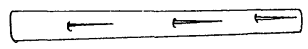

$1-1-1$
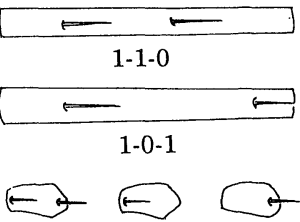

1p-1a $\quad 1 \mathrm{p}-0 \quad 0-1 \mathrm{a}$

27 Dorsal spines

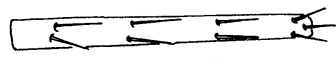

$2-2-2-3(1 d)$
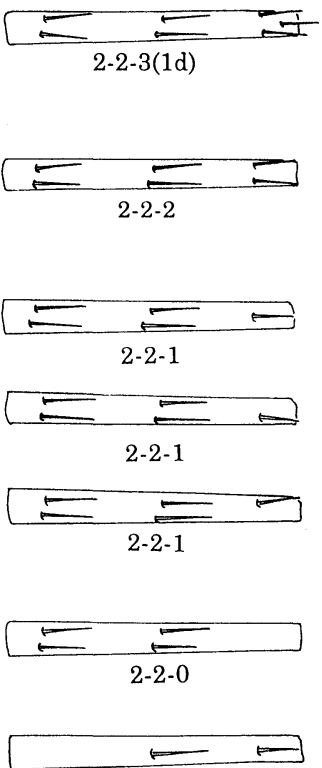

$0-1-1$
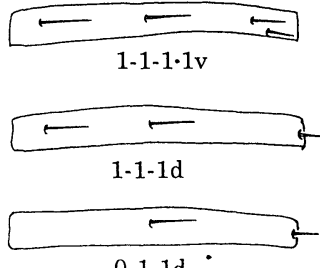

$0-1-1 d$

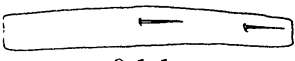

$0-1-1$

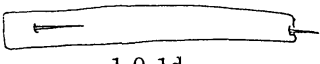

$1-0-1 d$
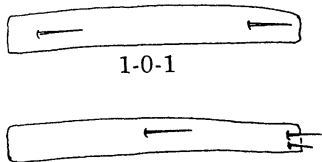

$0-1-1 d 1 v$
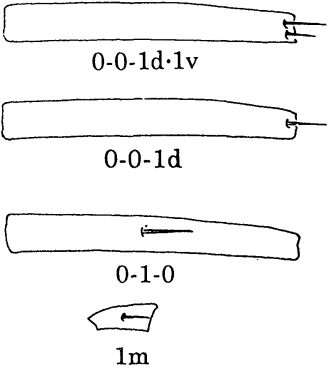

Ventral spines

Lateral spines

Fig. 27. Spiniformation of legs of Coelotes troglocaecus sp. n. (holotype, female).

external features and genital structure of the both species. This new species is troglobiontic spider, its body is smaller than that of $C$. okinawensis. It is easily distinguished from $C$. okinawensis and other congeneric species by the absence of eyes (Figs. $1,2)$, the pale coloration of body and spines, reduced numbers of marginal teeth of chelicerae and teeth on lower tarsal claws (Fig. 17), the absence of flecks on dorsal surface of carapace and abdomen, legs without ring flecks (Fig. 2), the diminutive projections on the epigynum and simple structure of genitalia (Figs. 10-12, Table 3).

Remarks: This new species lives freely under stones or weaves a simple sheet web among stones on the cave floor. Unlike Coelotes okinawensis, this species does not weave a tubular nest. On 8 July 1972, Shimojana witnessed this spider grasping and eating a juvenile cave cricket Diestrammena apicalis in Maya-gama cave (for locations, see Fig. 1). This event indicates that $C$. troglocaecus does not seem to employ the snarer foraging, but hunts moving prey on the cave floor. 


\section{Discussion}

In total and until 1998, 68 species of coelotine spiders have been reported from the areas around Japan including the Ryukyu Islands (35 spp.) (Nishikawa 1972, 1974, 1983a; Shimojana 1982, 1989; Yaginuma 1977, 1986, etc.), Taiwan (7 spp.) (Wang \& Ono 1998), Korea (14 spp.) and China (12 spp.) (Namkung 1980; Paik 1978; Schenkel 1936, etc.;). There are great differences between local faunistic data, but one species, Coelotes luctuosus (Koch 1878), is distributed all over these districts, except for Taiwan (Wan \& Ono 1998).

Two species, Coelotes luctuosus and C. corassides, are distributed in Korea and China. Of seven species of coelotine spiders, six from Taiwan except for $C$. xinhuiensis are endemic to Taiwan (Wang \& Ono, 1998). Five species including $C$. okinawensis, $C$. yaeyamensis, $C$. urumensis, $C$. kumensis and $C$. amamiensis are distributed in the middle and south Ryukyus, all of which are endemic to the Ryukyu Islands (Shimojana 1982, 1989).

A total of 19 species of cave-dwelling coelotine spiders have been reported from Japan (Shimojana 1979, 1982, 1989; Yaginuma 1963), Korea and China (Yaginuma 1976), seven of which were collected from limestone caves, six species from lava caves and the remaining four species from abandoned mines (Nishikawa 1972).

Cave spider fauna in the Ryukyu Islands has been studied by Shimojana (1977). Since then, extensive investigations have been carried out from 1978 to 1980 , and 260 caves including five abandoned artificial caves (shelters) were searched for spiders. Five coelotine spider species were obtained from 48 limestone caves on Okinawa Island and adjacent islands (Shimojana 1982, 1989). All the species of the genus Coelotes so far recorded from Japan have usually eight eyes and are brown or blackish brown in body coloration. This fact suggests that these species are troglophilic and scotophilic, but not troglobies.

The discovery of the eyeless coelotine spider Coelotes troglocaecus sp. $\mathrm{n}$. from the Ryukyu limestone caves on Okinawa Island is remarkable. This new species has been found only from six limestone caves that are located at 60 to $80 \mathrm{~m}$ in altitude. Therefore, the geographical distribution of this species may be a result of the past rise of sea level during Quarternary. Some of these limestone caves are distributed in the older Motobu limestone area formed in the Permian era and the others in the Ryukyu limestone area developed in the Pleistocene. However, we could not find any difference in morphological characters between the individuals collected in these two kinds of limestone caves. It may be necessary to conduct a further intensive survey for the distribution of this species in relation to the geological history of the Ryukyu Islands.

It is difficult to discuss individual variations in the morphological characters of Coelotes troglocaecus sp. $\mathrm{n}$. because only six specimens were collected, but certainly this species must be considered as smallest among the genus Coelotes. Although we have devoted great efforts in finding more specimens, especially males, neither a sufficient number of specimens nor even a single male could be found (Shimojana 1977, 1979, etc.).

Coelotes okinawensis, which occurs often sympatric with C. troglocaecus, is widely distributed in Okinawa Island and adjacent islands such as Izena, Kouri, Yagaji and Miyagi Isls., etc. Sometimes, Coelotes okinawensis has been collected in caves of Ryukyu limestone, but the morphological character of this species was not different from that of individuals living outside the caves in the same locality (pers. observ.).

According to previous studies, only two species have been known from Japan as 
eyeless troglobiontic spiders (Yaginuma 1972, 1986; Nishikawa 1983; Shimojana 1979, Irie 1998): Comaroma nakahirai (Yaginuma 1959) (Anapidae) and Cybaeus itsukiensis Irie 1998 (Cybaeidae). But in some individuals of a limited number of species such as Leptoneta caeca (Yaginuma 1972) and L. longipalpis (Leptonitidae) (Komatsu 1957) and Ablemma shimojanai (Tetrablemmidae) (Shimojana 1979), degeneration of eyes have been reported in various degrees. These three species are small, their body lengths being 1 to $3 \mathrm{~mm}$, and usually they have four to six eyes.

Coelotes troglocaecus is also small-sized, eyes and body color are completely degenerated (Figs. 2, 3). This species is a single troglobiontic coelotine spider, and the first eyeless coelotine spider ever recorded in Japan. The degenerated eyes, pale body coloration, and relatively long trichobothria seem characters adaptive to the cave environment, and such morphological adaptations have been commonly seen in true cave dwelling species including Apozomus daitoensis (Arachnida, Hubbardiidae) (Shimojana 1981) and Galloisiana bigryogensis (Coleoptera; Garyllobatidae) (Namkung 1974).

Seasonally, adults of Coelotes okinawensis appear in late October and the eggcocoons are found in late December. Adult females of Coelotes troglocaecus sp. n., on the other hand, were found from July to August, which is about 2 to 3 months earlier than the appearence of the sympatric congener C. okinawensis (unpubl. observ.).

Morphologically, the female of this species is distinguished by very diminutive sexual organs which bear only a single pair of small thin epigynal projections, degenerated copulatory openings, and simple structure of internal genitalia such as spermathecae and spermathecal ducts (Figs. 10-12), from any other Japanese congeners (compare Figs. 10-12 with Figs. 13-15 drawn for Coelotes okinawensis, a sexual congener. Also see Table 3). These degenerative features of genital organs, in combination with the fact that no males of the species have been found in spite of extensive and intensive searches, strongly suggest occurrence of thelytokous reproduction in this species. Thelytoky has been reported in a few species of spiders such as Dysdera hungarica (Dysderidae) (Deeleman-Reinhold 1986; Gruber 1990), Theotima feminina (Ocyroceratidae) (Machado 1964), and Isopoda insignis (Sparassidae) (Lake 1986), though the phenomenon seems to be much rarer in spiders than in harvestmen (Tsurusaki 1986). It has been often said that thelytoky is likely to be found in animals with low vagility or in animals isolated in a small restricted habitat, such as oceanic islands or caves (Tsurusaki 1983, 1986). In accordance with the statement, Theotima feminina is a cave dweller (Machado 1964) and Dysdera hugarica lacks ballooning (Deeleman-Reinhold 1986). Coelotes troglocaecus, an eyeless troglobie, may be another example of the rule. Further study including rearing experiments is needed for the confirmation of the thelytoky in this species.

\section{Acknowledgments}

We thank Dr. Y. Nishikawa, Otemon Gakuin University and Dr. N. Tsurusaki, Tottori University, for their offering us valuable literature for this study. We also wish to express our appreciation to Dr. J. Haupt, Technische Universität Berlin for his suggestion to the manuscript. We are much indebted to two anonymous referees for their useful comments to the manuscript.

\section{References}

Irie, T. 1998. A new eyeless spider of genus Cybaeus (Araneae: Cybaeidae) found in a limestone cave of Kyushu, Japan. Acta Arachnol., 47: 97-100. 
Deeleman-Reinhold, C. L. 1986. Dysdera hungarica Kulczynski. A case of parthenogenesis ? Actas X Congr. Int. Arachnol. Jaca/Espana, 1: 25-31.

Gruber, J. 1990. Fatherless spiders. Newsl. Br. Arachnol. Soc., No. 58, p. 3.

Koch, L. 1878. Japannische Arachniden und Myriapoden. Verh. Zool. Bot. Ges. Wien, 27: 735-789, pls., 15-16.

Komatsu, T. 1957. Some new cave spiders in Japan. Acta Arachnol., 14: 67-73.

Lake, D. C. 1986. Possible parthenogenesis of the huntman spider Isopoda insignis (Araneae, Sparasiidae). J. Arachnol., 14: 129.

Machado, A. de Barros. 1964. Sur l'existence de la parthenogenese dans quelques especes d'Araignees Ochyroceratides. C. R. Acad. Sc. Paris, 2: 5056-5059.

Namkung, J. 1974. A new species of Galliosiana (Gryllobalattidae) from Kosudong Cave in Korea. Korean J. Entomol., 4: 91-95.

Namkung, J. 1980. The spider fauna of Mt. Joryeong Area, Korea. Korean J. Entomol., 10: 33-42. (In Korean with a list of spiders from Mt. Toryeong area, Korea)

Nishikawa, Y. 1972. Arachnida from abandoned mines in the northern part of Osaka Prefecture. Fac. Let. Rev. Otemon Gakuin Univ., 6: 95-102.

Nishikawa, Y. 1974. Japanese spiders of the genus Coelotes (Araneae, Agelenidae). Fac. Let. Rev. Otemon Gakuin Univ., 8: 174-182. (In Japanese)

Nishikawa, Y. 1980. A new Coelotes (Araneae, Agelenidae) from central Japan. J. Speleol. Soc. Japan, 5: $38-42$.

Paik, K. Y. 1978. Illustrated Flora and Fauna of Korea. Vol. 21. Araneae. pp. 334-358. Ministry of Education. (In Korean)

Schenkel, E. 1936. Schwedisch-chinesische Wissenschaftliche Expedition nach den Nordwestlichen Provinzen Chinas. Ark. Zool., 29A; 1-134.

Shimojana, M. 1977. Preliminary report of cave spider fauna of the Ryukyu Archipelago. Acta Arachnol., 27(spec. no.): 337-365.

Shimojana, M. 1979. Cave animals in Okinawa island and adjacent islands. A report on the scientific survey of limestone caves in Okinawa Prefecture II. An Educational Committee in Okinawa Prefecture. pp. 75-111. (In Japanese)

Shimojana, M. 1981. A new species of the genus Trithyreus (Schizomida, Schizomidae) from the Daito Islands, Okinawa Prefecture, Japan. Acta Arachnol., 30: 33-40.

Shimojana, M. 1982. A new species of the Coelotes (Araneae, Agelenidae) from the Yaeyama Islands, Okinawa Prefecture, Japan. Acta Arachnol., 30: 75-82.

Shimojana, M. 1989. Four new species of genus Coelotes (Araneae, Agelenidae) from the Ryukyu Islands, Japan. Arachnol. Pap. Press. Yaginuma, Osaka, p. 75-82.

Tsurusaki, N. 1983. Why do parthenogenetic species prevail in the north ? Bull. Soc. Popul. Ecol., 37: 1-8. (In Japanese)

Tsurusaki, N. 1986. Parthenogenesis and geographic variation of sex ratio in two species of Leiobunum (Arachnida, Opiliones). Zool. Sci., 3: 517-532.

Yaginuma, T. 1963. Spiders from limestone caves of Akiyoshi Plateau. Bull. Akiyoshi-dai Sci. Mus., 2: 49-62. (In Japanese, partly with English summary)

Yaginuma, T. 1972. The fauna of the lava caves Mt. Fuji-san. IX. Araneae (Arachnida). Bull. Nat. Sci. Mus. Tokyo, 15: 267-334.

Yaginuma, T. 1976. Studies in cave spiders of Japan. Ess. Stud. Publ. Comm., 10th Anniv. Otemon Gakuin Univ., pp. 983-1018. (In Japanese)

Yaginuma, T. 1977. A list of Japanese spiders (revised in 1977). Acta Arachnol., 27(spec. no.): 367406.

Yaginuma, T. 1986. Spiders of Japan in Colour. New Edition. Hoikusha, Osaka. pp., 147-152. (In Japanese)

Wang, X. P. \& Ono, H. 1998. The coelotine spiders (Araneae, Amaurobiidae) of Taiwan. Bull. Matn. Sci. Mus. Tokyo, Ser. A, 24: 141-159.

(Received January 30, 2000/Accepted April 5, 2000) 


\section{Acta Arachnologica, Vol. 49, No. 1 掲載論文の和文要旨}

カタハリウズグモの生活史および隠れ帯二型の 出現頻度の季節変化 (pp. 1-12)

渡部 健( T606-8502 京都市左京区北白川追分 町, 京都大学大学院理学研究科生物科学専攻動 物生態学研究室)

京都大学理学部付属植物園内に生息するカ夕 ハリウズグモの生活史および，円網の隠れ帯二 型（直線型・ウズ型）の出現頻度の季節変化を 調查した. 調查地内のカタハリウズグモは二化 性で，夏世代と越冬世代をもっていた，産卵か ら幼体が出現するまでの時間は繁殖期間中に変 化した。おそらく, 卵発生における有効積算温 度の効果によるものと推測された．卵囊中の卵 数は, 保護している雌親の体重, および推定さ れる産卵前の雌親の体重と高い正の相関関係を 示した. 隠れ帯二型の出現頻度は季節変化し, 初夏には直線型が多く，秋に向けてウズ型の頻 度が増大する傾向を示した，直線帯をつけた網 の個体は，ウズ帯をつけた網の個体に較べ，体 重が重く，腹部の膨らみ度合が大きかったこと から，隠れ帯二型は，個体の栄養状態に対応し ていることが示唆された. 初夏から秋に向けて 餌となる飛翔昆虫量が減少することが, 隠れ帯 二型の出現頻度の季節変化に影響を与えている と推察した。

台湾産 Nesticella 属(クモ目：ホラヒメグモ科) の 1 新種（pp. 13-16)

卓 逸民 ${ }^{1}$, 吉田 哉 ${ }^{2}{ }^{1}$ 中華民國臺灣省臺中市中 港路三段 181 號, 東海大學生物系 ; ${ }^{2}$ T990-2484 山形市篭田 2 丁目 7 番 16 号)

台湾産ホラヒメグモ科 Nesticella Lehtinen \& Saaristo1980 属の 1 新種を記載した.この属は アジアからアフリカの熱帯地方に多く分布す る. 東アジアからは, Nesticella quelpartensis (Paik \& Namkung 1969), N. brevipes (Yaginuma 1970), N. mogera (Yaginuma 1972), N. okinawaensis (Yaginuma 1979), N. odonta (Chen 1984）および N. yui Wunderlich \& Song 1994 の
6 種がこれまで記録されている（Platnick 1997; Song et al. 1999). 今回記載した種はこの地域か らの 7 種目にあたる.

日本産 Eriophora 属のクモ類（クモ目：コガネ グモ科)（pp. 17-28）

谷川明男 (†248-0025 神奈川県鎌倉市七里ガ浜 東 2-3-1 神奈川県立七里ガ浜高等学校)

分岐分析に基づいて, これまで Zilla 属に置 かれていた日本産の 3 種のクモ類を Eriophora 属に移し, 再記載し図示した。また, 沖縄島産 Eriophora 属の 1 新種を記載した. 本論文であつ かったクモ類は, Eriophora sagana (Bösenberg \& Strand 1906) comb. nov. サガオニグモ, $E$. sachalinensis (S. Saito 1934) comb. nov. カラフ トオニグモ, E. sachalinensis (S. Saito 1934) comb. nov. キンカタハリオニグモおよびE. yanbaruensis sp. nov. ヤンバルオニグモ（新称） の 4 種である. Aranea sagana Bösenberg \& Strand 1906 を Aranea sagana (Keyserling 1893) の新参ホモニムから復活させ, Eriophora migra Zhu \& Song 1994は Eriophora sagana (Bösenberg \& Strand 1906) comb. nov. サガオニグモの, Eriophora flava Zhu \& Song 1994 は Eriophora sachalinensis (S. Saito 1934) comb. nov. カラフ トオニグモの新参シノニムとした.

\section{沖縄島から採集された無眼の真洞穴性ヤチグモ} 属の 1 新種 (pp. 29-40)

下謝名松榮 ${ }^{1}$-西平守孝 ${ }^{2}$ ( ${ }^{1}$ T903-0129 沖縄県西 原町子原 1 , 琉球大学教育学部理科教育; ${ }^{2}$ 个 980-8587 仙台市青葉区荒巻字青葉, 東北大学大 学院理学研究科生物学専攻)

沖縄本島の石灰洞から見つかった小型の洞穴 性ヤチグモを Coelotes troglocaecus n. sp. (オキ ナワホラアナヤチグモ）として記載した.ヤチ グモでは国内初の無眼種である。同所的に生息 する Coelotes okinawensis Shimojana 1989 オキ ナワヤチグモと比較しつつ形態記載をおこなっ 
た。本種は沖縄本島に固有で，石灰洞にのみ発 見される。個体群密度は非常に低い。これまで 雌のみしか採集されておらず，また，雌の外雌 器や交尾口の退化は, 本種が単為生殖をおこな っている可能性を強く示唆する. 本種は洞穴内 での生活に適応的とみられる形質を他にもいく つか備える. 琉球列島の地史に関連して, 洞穴 という生息場所への特化について議論した。

日本産アシダカグモ科, I. ミナミアシダカグモ 属(新称), アシダカグモ属, コアシダカグモ属 (新称)の 4 新種の記載および既知種についての 知見（クモ目：アシダカグモ科：ツユグモ亜科 およびアシダカグモ垔科)（pp. 41-60)

P. Jäger ${ }^{1}$ ・ 小野展嗣 ${ }^{2}$ ('Institut für Zoologie, Johannes Gutenberg-Universität, Germany ; ${ }^{2} \mathbf{T} 169$ -0073 東京都新宿区百人町 3-23-1 国立科学 博物館動物研究部)

日本産アシダカグモ科の Olios [ミナミアシダ カグモ属 (新称) ] の 1 新種, Heteropoda [アシ ダカグモ属］の 1 新種ならびに Sinopoda [コア シダカグモ属 (新称) ] の 2 新種の計 4 新種を以 下のように命名して記載した：Olios japonicus sp. nov. [ニホンミナミアシダカグモ (新称)], Heteropoda simplex sp. nov. [ホソミアシダカグ モ (新称, 細身の意)] Sinopoda okinawana sp. nov. [リュウキュウコアシダカグモ (新称) ], Sinopoda tanikawai sp. nov. [アマミコアシダカ グモ (新称)]. ミナミアシダカグモ属は日本か ら新たに記録された。そのほか, 本科のいくつ かの既知種について若干の分類学的知見と採集 記録を付記し, 日本産の亜科および属の特徴に ついて解説を加えた。

大陸アジア南部からのアシダカグモ亜科（アシ ダカグモ科) の 2 新属（pp. 61-71）

P. Jäger (Institut für Zoologie, Johannes Gutenberg-Universität, Germany)

大陸アジア南部からのアシダカグモ亜科（ア シダカグモ科）の 2 新属Pseudopoda と Bhutaniella を記載した。 それぞれPseudopoda prompta (O. P.-Cambridge 1885) と Bhutaniella hillyardi を模式種として指定し，記載した。 Heteropoda 属として記載されていた次の種は Pseudopoda に転属させた：P. casaria (Simon 1897), P. exigua (Fox 1938), P. exiguoides (Song \& Zhu 1999), P. grahami (Fox 1936), P. lushanensis (Wang 1990), P. virgata (Fox 1936), $P$. zhangmuensis (Hu \& Li 1983), P. zhejiangensis (Zhang \& Kim 1996). また, Heteropoda sikkimensis Gravely 1931 Bhutaniellaに移し た.両属とも分布は標高 $1000 \mathrm{~m}$ 以上の高所に限 られているようである。（和訳：編集委員会）

シベリアとモンゴルからのザトウムシの 2 新種 (1 新属) とウデブトザトゥムシ属の再定義（マ ザトウムシ科）（pp. 73-86）

鶴崎展巨 ${ }^{1}$, A. N. Tchemeris ${ }^{2}, \&$ D. V. Logunov ${ }^{3}$ ( ${ }^{1}$ T680-8551 鳥取市湖山町南 4-101 鳥取大 学教育地域科学部生物学教室; ${ }^{2}$ Dept. Invertebrate Zool., Fac. Biol. \& Soil Sci. Tomsk State University, Tomsk, Russia ; ${ }^{3}$ Zool., Mus., Biol. Instit. Siberian Div. Russ. Acad. of Sci., Novosibirsk, Russia)

シベリアからマザトウムシ科の Acanthomegabunus sibiricus を新属新種として，また， モンゴル南ゴビ地方からウデブトザトウムシ属 の 1 種 Homolophus gobiensis を新種として記載 した. ウデブトザトウムシ属については再定義 を与え, Phalangium pallens Kulczynski を本属 に,また Homolophus potanini を Opilio 属に移 した. Opilio asiaticus Gricenko は Opilio potanini (Simon) の後行異名とした.

シベリア南部からのウデザトウムシScleropilio insolens の再記載とウデザトウムシ属の 改訂 (pp. 87-94)

鶴崎展巨 ${ }^{1}$, A. N. Tchemeris, \& D. V. Logunov ${ }^{3}$ ( ${ }^{1}$ T680-8551 鳥取市湖山町南 4-101 鳥取大 学教育地域科学部生物学教室 ; ${ }^{2}$ Dept. Invertebrate Zool., Fac. Biol. \& Soil Sci. Tomsk State University, Tomsk, Russia ; ${ }^{3}$ Zool. Mus., Biol. Instit. Siberian Div. Russ. Acad. of Sci., Novosibirsk, Russia) 